\title{
Assessing Sensory Perception on the Vulva and on Extragenital Sites
}

\author{
Miranda Farage*, ${ }^{*}$, Kenneth W. Miller ${ }^{1}$, Denniz Zolnoun ${ }^{2}$ and William J. Ledger ${ }^{3}$ \\ ${ }^{1}$ Feminine Clinical Sciences, The Procter \& Gamble Company, Cincinnati OH, USA \\ ${ }^{2}$ Department of Obstetrics \& Gynecology and Center for Neurosensory Disorders, Pelvic Pain Research Unit, \\ University of North Carolina, Chapel Hill, North Carolina, USA \\ ${ }^{3}$ Department of Obstetrics and Gynecology, The New York-Presbyterian Hospital, Weill Medical College of Cornell \\ University, New York, NY, USA
}

\begin{abstract}
Quantitative sensory testing (QST) measures perception thresholds of defined intensities of physical stimuli (e.g. temperature, touch, pressure, vibration). The frequency and severity of subjective sensory effects (itch, burn), though less quantifiable, can be characterized under defined conditions such as product testing. This article reviews two sources of published research on sensory perception on the vulva relative to extragenital sites: (1) systematic, quantitative sensory testing with defined stimuli and (2) vulvar sensory effects reported in clinical trials of external feminine hygiene products. In healthy women, the vulva is less sensitive to punctate touch and vibration than other body sites. Vulvar sensitivity to mechanical stimuli declines after menopause, but is restored by estrogen supplementation. Product trials of feminine wet wipes suggest that vulvar perception of stinging and of skin wetness also are attenuated after menopause, although perceptions of burning or itching appeared to be unaffected. More systematic, standardized conditions are needed to validate the continued use of QST on the vulva and to better define the characteristics and intensity of subjective vulvar sensations.
\end{abstract}

Keywords: Vulva, vagina, extragenital anatomical sites, quantitative sensory testing, subjective sensory effects, menopause, estrogen, prospective clinical trials.

\section{INTRODUCTION}

Research on sensory perception of the vulva has focused largely on the sexual response and on the sensation of pain in pathological conditions such as provoked vestibulodynia (vulvar vestibulitis syndrome) and idiopathic vulvodynia. Our laboratories are interested in better characterizing vulvar sensory perception in healthy women, the factors that affect it, and any insights that might apply to the products research or clinical settings. This article reviews two sources of information on vulvar sensation: (1) quantitative sensory testing (QST), which measures the perception thresholds of quantifiable stimuli such as temperature, touch, pressure, and vibration; (2) subjective sensory effects (wetness, dryness, itch, burning, stinging) reported by women who used external feminine hygiene products under controlled conditions. For perspective, trends in the sensory perception of extragenital skin in comparison to vulvovaginal tissue are also summarized. Although the research on vulvar sensation is very limited, objective QST and surveys of subjective sensation experienced in product trials provide complementary information about sensory perception on the vulva and the effects of variables such as age, the menstrual cycle, and menopause.

*Address correspondence to this author at the Procter \& Gamble Company, Winton Hill Technical Center, Box 136, 6110 Center Hill Rd, Cincinnati, OH 45224, USA; Tel: (513) 634-5594; Fax: (866)-622-0465;

E-mail: farage.m@pg.com

\section{NEURAL SENSATION OF PHYSICAL STIMULI}

It is helpful to briefly review how the perception of sensation is mediated by the nervous system. In glabrous and semiglabrous skin, the sensation of mechanical stimuli (touch, pressure, and vibration) and the sensations of temperature and pain are mediated by different parts of the nervous system. Touch, pressure, and vibration are detected by specialized mechanoreceptors: rapidly adapting receptors, such as Meissner corpuscles and Pacinian corpuscles, detect transient light touch and transient deep pressure, respectively; slowly adapting receptors, such as Merkel cells and Ruffini receptors, respond to more sustained touch, such as sensing texture or shape. The sensory input from these mechanoreceptors is conducted by large myelinated fibers in the peripheral nerves and by the dorsal column of the spinal cord.

Temperature and pain are detected by free nerve endings in the skin; the sensory input is conducted by the small fiber system and its central connections in the spinothalamic tracts. Moreover, within the small fiber system, different fibers convey sensory impulses in response to temperature and pain: thinly myelinated fibers convey impulses from heat and cold receptors and unmyelinated fibers convey impulses from nociceptors that respond to painful or noxious stimuli. Sensory information transmitted along the spinal cord is ultimately processed via the thalamus to be interpreted by the cerebral cortex and cerebellum.

Various sensory nerves innervate the vulva and perineum (Fig. 1): the posterior femoral nerve innervates the latter as- 
pect of the perineum posteriorly and the lateral margin of the vulva superiorly along the leg crease; the genitofemoral and illioinquinal nerves (originating from L1-L2) innervate the mons pubis and upper labia majora, approximately to the level of the urethra; and the perineal branch of the pudendal nerve (from sacral roots S2-S4), which is viewed by most clinicians as the primary source of vulvar innervation (lobes of the labia majora through the vestibule). A network of nerves over the dorsal aspect of the glans clitoris arises from the deeper pudendal nerve. Coverage of the vulva can also include the inferior cluneal nerve, which originates from S1$\mathrm{S} 3$. The correlation between these anatomical details and the characteristics of vulvar sensation and pain is not wellcharacterized, and mapping these relationships is an area of active research in our laboratories [1].

\section{QUANTITATIVE SENSORY TESTING}

Quantitative sensory testing (QST) is used to quantify sensory function in healthy people and in patients at risk for neurological impairment [2]. It is also employed to assess factors that affect pain perception [3-5]. In QST, a measurable stimulus is applied to the skin and the subject or patient reports his or her perception of it. The method employs calibrated instruments to deliver known intensities of physical stimuli, for example, mild electric current (by means of surface electrodes), temperature (via electric thermodes with controlled surface temperatures), touch (using filaments whose bending force depends on diameter and length), pressure (exerted by spring-loaded devices), and vibration (using tuning forks or vibrators that deliver sinusoidal stimuli at a given frequency). Stimulus of a given intensity is applied,

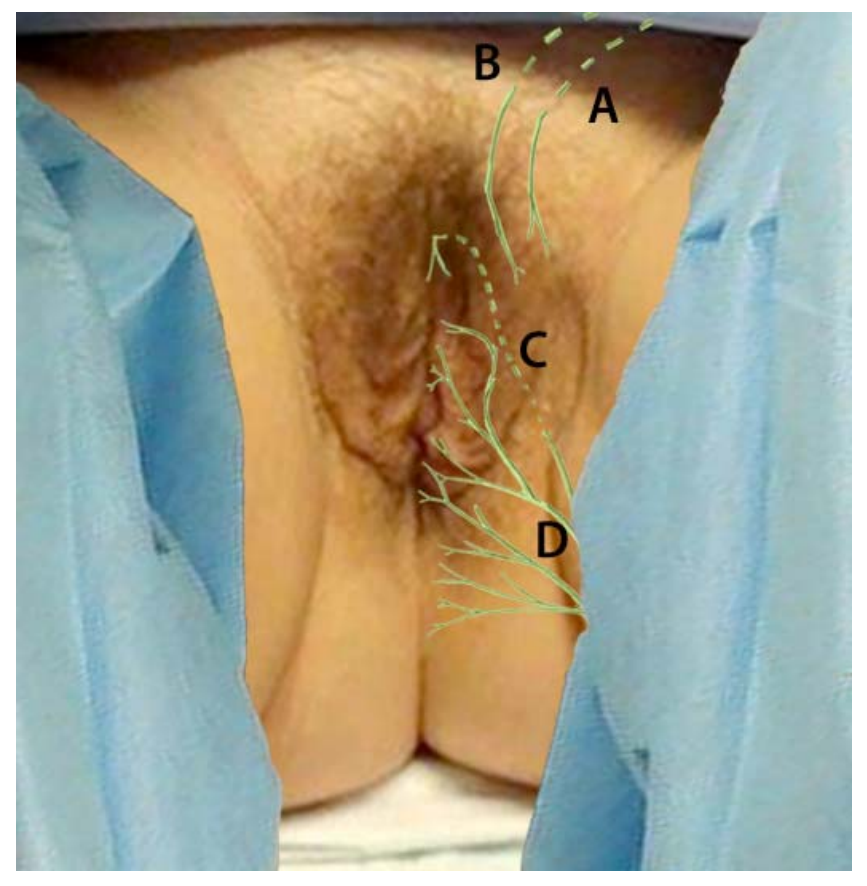

Fig. (1). Schematic of the innervation of the vulva.

A. Anterior labial branches of illoinguinal nerve; B. Genitofemoral nerve; C. Dorsal nerve of the clitoris (continuation of pudendal nerve shown deeper (as dashed lines) in muscles of urogenital diaphragm; D. Branches of pudendal nerve. and the subject reports whether or not the stimulus is perceived (or, in pain studies, whether or not the stimulus elicits pain). The lowest intensity that is perceptible (or, if pertinent, painful) is the detection threshold.

Two general methods are employed to determine these thresholds: (1) the method of limits, and (2) the method of levels. With the method of limits, the stimulus is progressively increased and the subject declares when it first becomes perceptible. With the method of levels, stimulus of a defined intensity is applied, then increased or decreased by specific increments depending on whether or not the subject perceives it. (Protocols may differ in terms of the number of consistent responses required to progress upward or downward in stimulus intensity.)

With the method of limits, sensory information is processed neurologically at the same time as the stimulus intensity is being changed. The inherent response lag leads to a small error in threshold measurement; consequently, thresholds measured with the level of limits skew higher than those measured with the method of levels [6,7]. Moreover, the rate of change of the stimulus affects thresholds obtained by the method of limits

The method of levels is known as "forced-choice", as the subject must declare or "choose" whether or not the stimulus is perceived. Because this method takes longer and is more repetitive, error can result if the subjects become fatigued or distracted as the test proceeds.

Experimental variables such as the application site, the surface area of contact, the frequency of the stimulus (in the case of vibration), and the rate of change of stimulus intensity, affect the absolute value of thresholds measured. Consequently, the absolute values measured are a function of the experimental conditions employed, and the lack of standardization complicates comparisons between experiments. This review will focus on the relative thresholds assessed within experiments (e.g. thresholds measured at different anatomical sites, or in people from of different ages) to draw conclusions about variables that affect sensory perception.

\section{SENSORY THRESHOLDS ON EXTRAGENITAL SITES}

Before discussing sensory perception on the vulva, it is helpful to review what is known about responses at extragenital sites. Table $\mathbf{1}$ summarizes some representative QST studies. The research shows that sensitivity to touch, vibration, and thermal stimuli varies by site. For example, the hands appear to be more sensitive to touch, and especially to vibration, than the feet $[2,8]$.

Of the various demographic (age, gender, ethnicity) and anthropometric variables (height, weight, side of the body) that have been studied, advancing age appears to have the most significant effect on sensory perception. QST of the hand and foot shows that sensitivity to mechanical stimuli (touch and vibration) declines with age. The decline becomes apparent by the fifth decade and progresses exponentially after age 65 or $70[9,10]$. The rate of decline differs by site. For example, thresholds of perception of touch and vibration remain approximately constant on the face, but the sensitivity to touch on the hands declines rapidly with advancing age 
Table 1. Factors Affecting Sensory Thresholds at Extragenital Sites

\begin{tabular}{|c|c|c|c|c|c|c|c|}
\hline $\begin{array}{l}\text { Popula- } \\
\text { tion }\end{array}$ & $\mathbf{N}$ & Stimulus & Method & $\begin{array}{l}\text { Anatomic } \\
\text { location }\end{array}$ & Results & Comments & References \\
\hline $\begin{array}{l}\text { USA } \\
\text { Children to } \\
\text { adults aged } \\
\text { 3-79 years }\end{array}$ & 350 & Vibration & $\begin{array}{l}\text { Stimuli: } \\
128 \mathrm{~Hz} \text { Rydel- } \\
\text { Seiffer tuning } \\
\text { fork applied } \\
\text { perpendicu- } \\
\text { larly to skin } \\
\text { surface } \\
120 \mathrm{~Hz} \text { hand- } \\
\text { held electro- } \\
\text { magnetic } \\
\text { Vibrameter }\end{array}$ & $\begin{array}{l}\text { Dorsum of } \\
\text { hands } \\
\text { Dorsum of } \\
\text { feet }\end{array}$ & $\begin{array}{l}\text { Hands more sensitive than feet } \\
\text { Perception threshold men > women } \\
\text { over } 50 \\
\text { Perception threshold unaffected by } \\
\text { age up to age } 17.9 \text {. } \\
\text { Perception threshold increased } \\
\text { substantially in adults aged } 70-79 \\
\text { compared to those aged } 18-29 \\
(30 \% \text { increase on hands and } 41 \% \\
\text { increase on feet in by Vibrame- } \\
\text { ter }\end{array}$ & $\begin{array}{l}\text { Absolute levels depend } \\
\text { on method used } \\
\text { The two methods were } \\
\text { correlated (r=0.954) } \\
\text { Retest reliability was } \\
\text { high } \\
\text { Results not affected by } \\
\text { skin temperature, body } \\
\text { side, weight, or height }\end{array}$ & [10] \\
\hline $\begin{array}{l}\text { Nether- } \\
\text { lands } \\
\text { Healthy } \\
\text { volunteers } \\
\text { aged 21- } \\
92\end{array}$ & 71 & $\begin{array}{l}\text { Temperature } \\
\text { (heat/cold) }\end{array}$ & $\begin{array}{l}\text { Peltier ther- } \\
\text { mostimulator } \\
3 \times 4 \mathrm{~cm} \text { double } \\
\text { probe surface. }\end{array}$ & $\begin{array}{l}\text { Foot dor- } \\
\text { sum }\end{array}$ & $\begin{array}{l}\text { Sig, increase in warm and cold } \\
\text { thresholds with age } \\
\text { Women had lower thresholds than } \\
\text { men }\end{array}$ & $\begin{array}{l}\text { Similar decline with age } \\
\text { for both warm and cold } \\
\text { thresholds }\end{array}$ & [8] \\
\hline $\begin{array}{l}\text { USA } \\
\text { Healthy } \\
\text { adults } \\
\text { Age 19-84 }\end{array}$ & 48 & $\begin{array}{l}\text { Temperature } \\
\text { in- } \\
\text { crease/decreas } \\
\mathrm{e} \\
\text { Tactile skin } \\
\text { indentation } \\
\text { Vibration }\end{array}$ & $\begin{array}{l}\text { Peltier }{ }^{\mathrm{TM}} \\
\text { thermal trans- } \\
\text { ducer, probe } \\
\text { surface } 7.1 \\
\mathrm{~cm}^{2} \\
\text { Skin clamp, } 1 \\
\mathrm{~mm} / \mathrm{sec} \text {; in- } \\
\text { dentation } \\
\text { range } 3-170 \\
\mu \mathrm{m} \text { or } 63- \\
1640 \mu \mathrm{m}, 2.9 \\
\mathrm{~cm}^{2} \text { area } \\
40 \mathrm{~Hz} \text { and } 250 \\
\mathrm{~Hz} \text { transducer }\end{array}$ & $\begin{array}{l}\text { Hand } \\
\text { (thenar } \\
\text { eminence) } \\
\text { Foot (plan- } \\
\text { tar surface) }\end{array}$ & $\begin{array}{l}\text { Young men more sensitive than } \\
\text { young women to warm stimuli on } \\
\text { the feet. } \\
\text { In young adults, hands more sensi- } \\
\text { tive than feet } \\
\text { Older individuals' feet less sensi- } \\
\text { tive to warm } \\
\text { Older hands \& feet, less sensitive } \\
\text { to skin indentation \& vibration }\end{array}$ & $\begin{array}{l}\text { Losses in sensitivity to } \\
\text { mechanical stimuli in } \\
\text { older adults was apparent } \\
\text { by fifth decade and was } \\
\text { more severe at lower } \\
\text { extremities }\end{array}$ & [11] \\
\hline
\end{tabular}




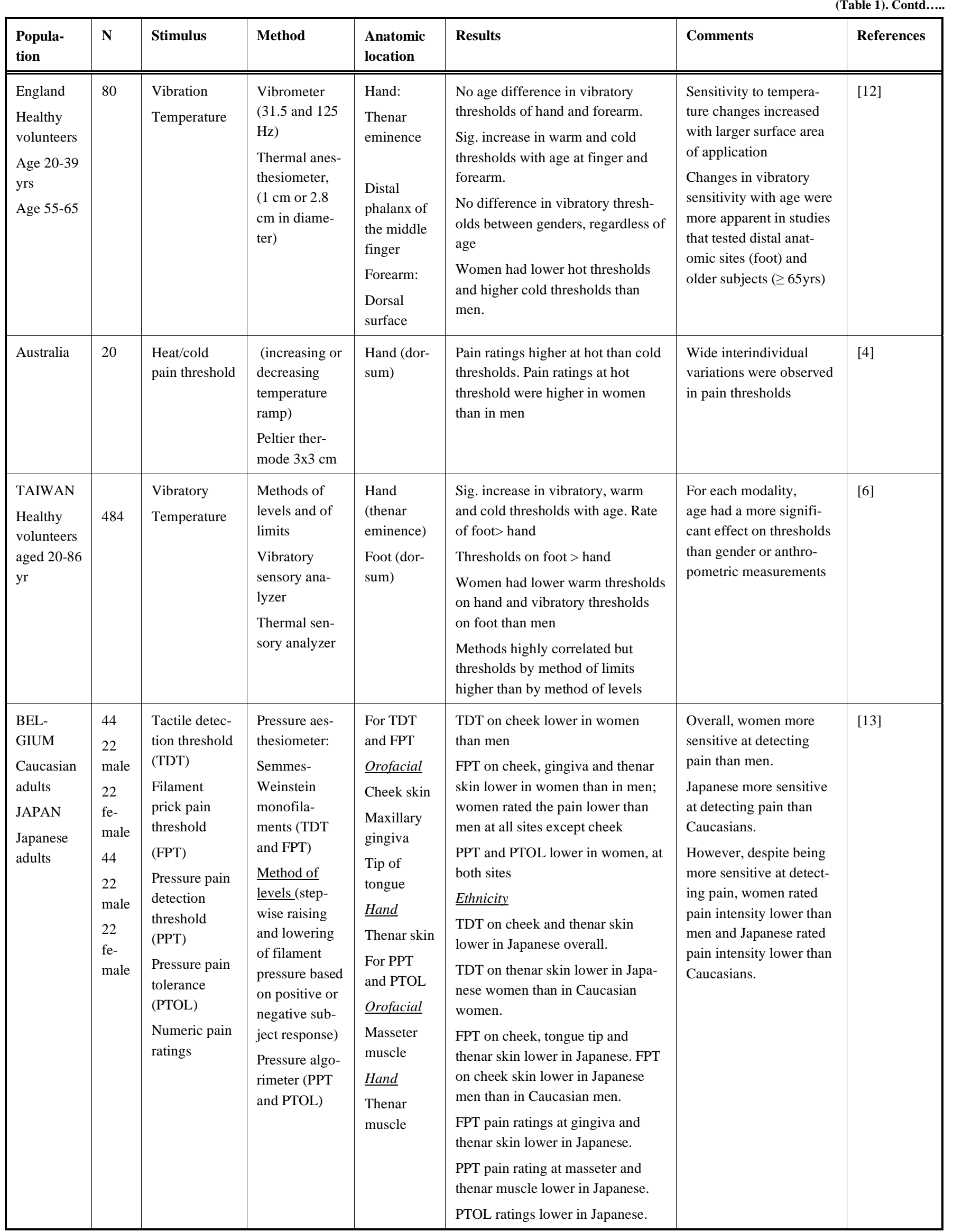


[2]. Moreover, age-related losses in sensitivity to vibration or skin indentation are more severe for the lower extremities [6, $10,11]$, perhaps reflecting the longer distance of the neural pathway that the sensory input must travel.

Some evidence exists that thermal thresholds also decline with age, but the effect may be weaker or less consistent at various sites $[6,8,9,12]$, as several studies show no change. Interestingly, a British study of people aged 20-39 and 55-65 detected an age-related decrease in sensitivity to warm and cold stimuli on the finger and forearm, but only with a probe having a surface area of $2.8 \mathrm{~cm}^{2}$, not with a probe of $1 \mathrm{~cm}^{2}$. Moreover, the absolute heat perception thresholds were lower and cold perception thresholds higher overall when the larger probe was used [12]. This indicates that contact area affects the absolute values of experimentally determined perception thresholds.

Gender differences in sensory perception have been found, but not consistently. The degree of difference in sensitivity between men and women may depend on the age range studied, the anatomical sites assessed, and the sample size. With regard to mechanical stimuli, several studies found no gender differences in perception thresholds on the forehead [2]; on the hand, distal phalanx of the middle finger, or dorsal surface of the forearm, regardless of age [12]; or on the thenar eminence of the hand or plantar surface of the foot [11]. However, some studies have detected genderrelated differences in the perception of mechanical stimuli. A US study of 350 people found that, among those aged over 50 , women were more sensitive to vibration on the dorsum of the hands and feet than men [10]; similarly, vibratory thresholds among 484 Taiwanese were lower in women than in men on the dorsum of foot but no different on the thenar eminence of the hand [6]. A study of 44 Belgian and Japanese subjects found that, in both ethnic groups, women were more sensitive than men to filament touch on the cheek and to filament prick pain and pressure pain on the cheek, gingiva, and thenar skin [13].

With respect to the effect of gender on thermal sensitivity, some but not all studies found women to be more sensitive than men. The ethnicity and age range of the subjects as well as the anatomical sites examined varied among studies. A Dutch study found women to be more sensitive to thermal stimuli on the foot than men [8]. A Taiwanese study of 484 people found women to be more sensitive to warm thresholds on the both the thenar eminence of the hands and the dorsal surface of the feet than men [6]. A British study similarly found women to be more sensitive to heat and cold stimuli on the thenar eminence of the hand, the distal phalanx of the middle finger, and the dorsal surface of the forearm [12]. However, a North American study of 48 people found men aged 19-31 to be more sensitive to warm stimuli on the plantar surface of the feet compared to women in the same age group, but not on the thenar eminence of the hand [11].

One fairly consistent finding is that perception thresholds of mechanical and thermal stimuli and heat pain differ between distal and proximal limbs. In a group of 48 healthy American adults, the hands were more sensitive to heat pain than the feet, although no age- or gender-dependent differences were found [11]. In this study, heat pain thresholds increased when repetitive temperature reversals were made, suggesting either a sensory or affective adaptation to pain. However, in an Australian study among 20 subjects, prior exposure to the experimental conditions did not affect pain detection thresholds [4]. Adaptation may depend on the experimental conditions employed.

Ethnic differences in sensory perception also have been reported. For example, Japanese subjects were more sensitive to touch on the cheek and the thenar eminence of the hand than Caucasians. This group also was quantitatively more sensitive to pain elicited by a filament prick to the cheek, tongue, or thenar skin or to pressure on the masseter muscle of the jaw and thenar muscle of the hand [13]. However, the Japanese subjects rated the pain as less severe on a subjective scale than Caucasians despite being more sensitive at perceiving it. In the study just cited, cultural stoicism may have contributed to a higher tolerance to pain in the Japanese although though their perception thresholds were measurably lower. In the United States, quantitative studies comparing Hispanic, African American, and Caucasian ethnic groups have found that Hispanics [14] and African Americans [3, 14-16] have comparable pain perception thresholds to Caucasians but exhibit a lower pain tolerance. Studies suggest that among African Americans, both social factors (such as high levels of stress) as well as physiological changes in endogenous mechanisms of pain regulation may contribute to lower pain tolerance in this group $[17,18]$. The interpretation of ethnic differences in pain perception is controversial and no consensus exists on whether such differences result from physiological or cultural influences. A comprehensive discussion of the causes and implications of ethnic differences in pain perception is beyond the scope of this review.

\section{VULVOVAGINAL SENSORY THRESHOLDS}

Published quantitative testing on vulvovaginal sensory thresholds is summarized in Table 2. Studies that compared vulvovaginal sensory perception to sensory perception at other anatomical sites suggest that the vulva and vagina are relatively less sensitive to sensory stimuli. For example, among 58 premenopausal women in the Netherlands, the labia majora, labia minora, and clitoris were sensitive to mild electric current than the lower abdomen or the dorsum of the hand; the vaginal wall was the least sensitive site studied [19]. A Canadian study of 40 premenopausal women found the labium minus and the mucosa of the vulvar vestibule to be less sensitive than the forearm to filament touch and pressure, although the labium minus was more sensitive to pain than the forearm [20]. Similarly, a Canadian study of 13 premenopausal women found the vulvar vestibule to be less sensitive to filament touch and pressure than the deltoid muscle, the forearm, or the thigh [21].

When vibratory thresholds were considered, a Swedish study found the clitoris to be less sensitive to the perception of vibration than the dorsum of the hand but more sensitive than the dorsum of the feet [22]. A study of vibratory thresholds performed in Turkey found that vulvar sites (labia majora and minora, clitoris, and vaginal introitus) were comparable in sensitivity to the first and second fingers and to the nipples; in this study, the ears and lips were the least sensitive to vibratory stimuli [23]. 
Table 2. Factors Affecting Vulvovaginal Sensory Thresholds

\begin{tabular}{|c|c|c|c|c|c|c|c|}
\hline Population & $\mathbf{N}$ & Stimulus & Method & Anatomic location & Results & Comments & References \\
\hline $\begin{array}{l}\text { USA } \\
\text { Healthy and } \\
\text { neurologically } \\
\text { impaired } \\
\text { women }\end{array}$ & $\begin{array}{l}38 \\
32 \text { healthy } \\
5 \text { impaired } \\
\text { Premenopausal } \\
17 \\
\text { Postmenopausal } \\
15 \\
6 \text { with ERT } \\
9 \text { without ERT } \\
\text { Normoestrogenic } \\
\text { (premenopausal } \\
\text { and postmeno- } \\
\text { pausal women } \\
\text { on ERT) } \\
23 \\
\text { Hypoestrogenic: } \\
\text { (Postmenopausal } \\
\text { women not on } \\
\text { ERT) } \\
9 \\
\text { Neurologically } \\
\text { impaired women } \\
\text { compared to } \\
\text { controls matched } \\
\text { by age, parity } \\
\text { and estrogen } \\
\text { status } \\
\text { Impaired sexual } \\
\text { function (by } \\
\text { questionnaire) }\end{array}$ & $\begin{array}{l}\text { Pressure/ } \\
\text { touch }\end{array}$ & $\begin{array}{l}\text { Pressure aesthe- } \\
\text { siometer: } \\
\text { Semmes- } \\
\text { Weinstein } \\
\text { monofilaments } \\
\text { Method of limits: } \\
\text { sequential appli- } \\
\text { cation of pressure } \\
\text { filaments to point } \\
\text { of detection }\end{array}$ & $\begin{array}{l}\text { Vulva/perineum } \\
\text { Clitoral glans } \\
\text { Labium minus (right } \\
\text { and left) } \\
\text { Perineum } \\
\text { (right and left) } \\
\text { Anal verge } \\
\text { Average vulvar score } \\
\text { (all sites) }\end{array}$ & $\begin{array}{l}\text { Significant loss } \\
\text { of sensitivity to } \\
\text { pressure/touch } \\
\text { in postmeno- } \\
\text { pausal women } \\
\text { hypoestrogenic } \\
\text { women, women } \\
\text { with vulvar } \\
\text { atrophy, neu- } \\
\text { rologically } \\
\text { impaired } \\
\text { women, and } \\
\text { women with } \\
\text { impaired sexual } \\
\text { function. }\end{array}$ & $\begin{array}{l}\text { A clear effect } \\
\text { of estrogen on } \\
\text { vulvar sensi- } \\
\text { tivity was } \\
\text { demonstrated: } \\
\text { menopause, } \\
\text { non-use of } \\
\text { ERT, and } \\
\text { vulvovaginal } \\
\text { atrophy were } \\
\text { associated } \\
\text { with decreased } \\
\text { sensitivity to } \\
\text { pres- } \\
\text { sure/touch. } \\
\text { Although } \\
\text { vulva has } \\
\text { lower density } \\
\text { of estrogen } \\
\text { receptors than } \\
\text { vagina, effect } \\
\text { of estrogen on } \\
\text { touch sensitiv- } \\
\text { ity appears } \\
\text { profound. }\end{array}$ & [8] \\
\hline $\begin{array}{l}\text { USA } \\
\text { Postmenopausal } \\
\text { hypoestrogenic } \\
\text { women with } \\
\text { lower genitou- } \\
\text { rinary tract } \\
\text { complaints } \\
\text { (e.g. urinary } \\
\text { incontinence, } \\
\text { frequency, } \\
\text { urgency, noc- } \\
\text { turia, vaginal } \\
\text { atrophy) }\end{array}$ & $\begin{array}{l}39 \\
\text { ( } 30 \text { completed } \\
\text { study) }\end{array}$ & $\begin{array}{l}\text { Pressure/ } \\
\text { touch }\end{array}$ & $\begin{array}{l}\text { Protocol } \\
\text { RCT: topical } \\
\text { application of } \\
\text { estradiol cream to } \\
\text { vulvar vestibule } \\
\text { and vagina, } \\
\text { nightly for } 2 \\
\text { weeks, then } 3 \mathrm{x} \\
\text { weekly for } 2 \text { wks, } \\
\text { and } 2 \text { X weekly } \\
\text { for } 2 \text { more weeks, } \\
\text { with or without } \\
\text { pelvic muscle } \\
\text { biofeedback. } \\
\text { Intervention } \\
\text { groups: } \\
\text { (1) Active cream } \\
\text { with biofeedback; } \\
\text { (2) active cream } \\
\text { with sham bio- } \\
\text { feedback; (3) } \\
\text { Placebo cream } \\
\text { with biofeedback; } \\
\text { (4) Placebo cream } \\
\text { with sham } \\
\text { biofeedback } \\
\text { Outcome measure } \\
\text { Method of limits: } \\
\text { (1) Von-Frey } \\
\text { monofilament } \\
\text { thresholds (mN) } \\
\text { at vulvar vesti- } \\
\text { bule } \\
\text { (2) Maximum } \\
\text { intravaginal pres- } \\
\text { sure }\end{array}$ & $\begin{array}{l}\text { Vulvar vestibule } \\
\text { Vaginal wall }\end{array}$ & $\begin{array}{l}\text { Estradiol treat- } \\
\text { ment signifi- } \\
\text { cantly in- } \\
\text { creased sensi- } \\
\text { tivity of vesti- } \\
\text { bule to pres- } \\
\text { sure/touch } \\
\text { relative to } \\
\text { placebo at } 4 \\
\text { and } 6 \text { weeks. } \\
\text { Greatest im- } \\
\text { provements } \\
\text { occurred in } \\
\text { women aged } \\
70-79 \text { yrs }\end{array}$ & $\begin{array}{l}\text { Mechanism of } \\
\text { estrogen ac- } \\
\text { tion on sen- } \\
\text { sory function } \\
\text { of vestibule } \\
\text { not known. } \\
\text { Potential } \\
\text { sensorineural } \\
\text { targets may be } \\
\text { C fibers or } \\
\text { Merkel cells. }\end{array}$ & [26] \\
\hline
\end{tabular}


(Table 2). Contd.....

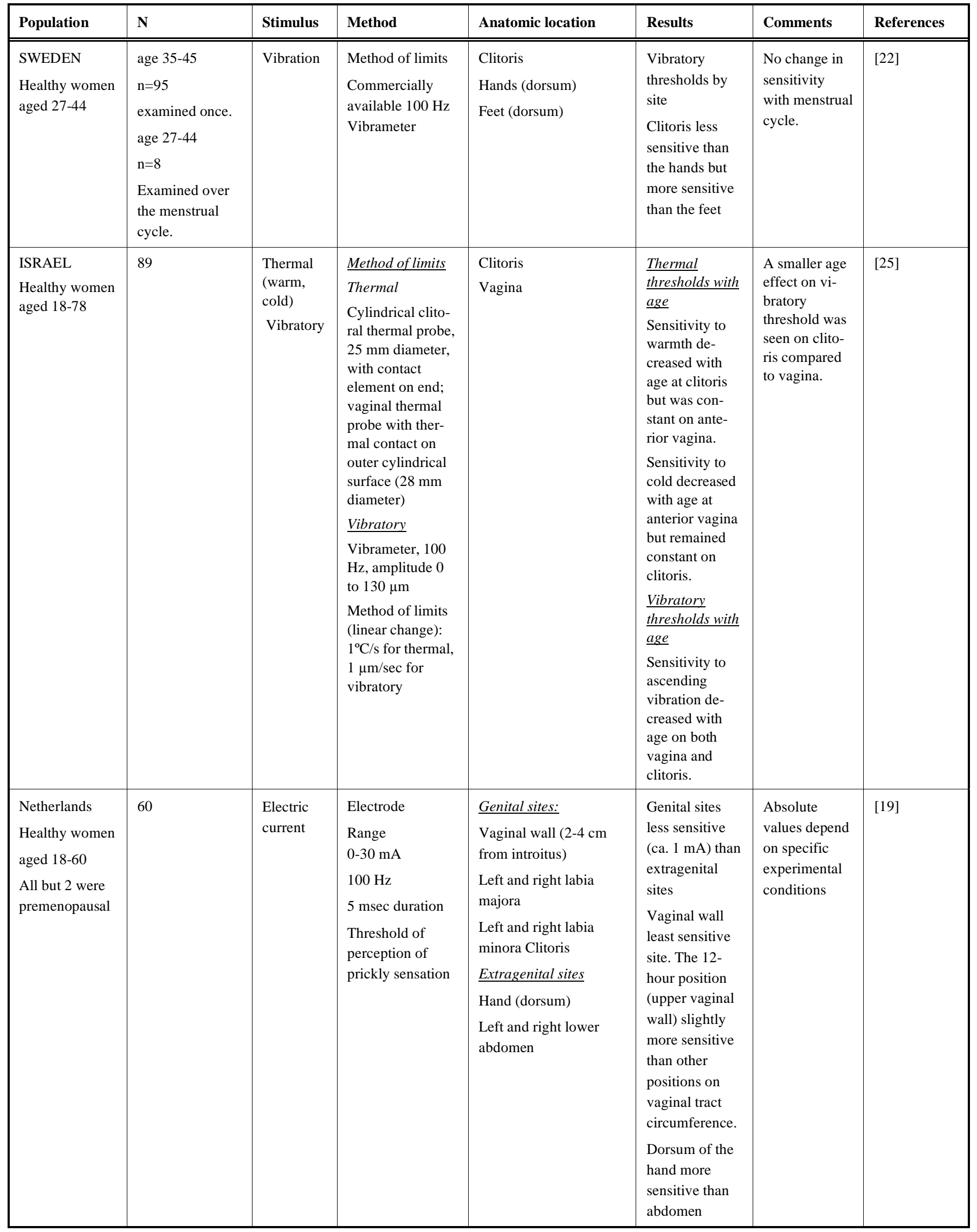


(Table 2). Contd.....

\begin{tabular}{|c|c|c|c|c|c|c|c|}
\hline Population & $\mathbf{N}$ & Stimulus & Method & Anatomic location & Results & Comments & References \\
\hline $\begin{array}{l}\text { USA } \\
\text { Women aged } \\
20-78 \\
\text { Examined } \\
\text { variables of } \\
\text { age, meno- } \\
\text { pause, prior } \\
\text { vaginal delivery } \\
\text { and history of } \\
\text { neurological } \\
\text { disorder }\end{array}$ & $\begin{array}{l}58 \\
10 \\
\text { age } 20-29 \\
13 \\
\text { age } 30-39 \\
17 \\
\text { age } 40-49 \\
8 \\
\text { age 50-59 } \\
10 \\
\text { age } 60-79\end{array}$ & Vibration & $\begin{array}{l}\text { Method of limits } \\
\text { Commercially } \\
\text { available } 120 \mathrm{~Hz} \\
\text { biothesiometer }\end{array}$ & $\begin{array}{l}\text { Vulva } \\
\text { Clitoris } \\
\text { External urethral mea- } \\
\text { tus } \\
\text { Right and left perineum } \\
\text { Medial right ankle }\end{array}$ & $\begin{array}{l}\text { Age } \\
\text { Vibratory sen- } \\
\text { sation thresh- } \\
\text { olds progres- } \\
\text { sively increased } \\
\text { with age at } \\
\text { vulva, clitoris, } \\
\text { external ure- } \\
\text { thral meatus } \\
\text { and ankle } \\
\text { Menopause } \\
\text { Sensitivity to } \\
\text { vibration de- } \\
\text { creased after on } \\
\text { genital sites but } \\
\text { not ankle }\end{array}$ & $\begin{array}{l}\text { Age affected } \\
\text { both genital } \\
\text { and peripheral } \\
\text { sensation } \\
\text { Menopause } \\
\text { affected geni- } \\
\text { tal sensation } \\
\text { only }\end{array}$ & {$[23]$} \\
\hline
\end{tabular}


(Table 2). Contd.....

\begin{tabular}{|c|c|c|c|c|c|c|c|}
\hline Population & $\mathbf{N}$ & Stimulus & Method & Anatomic location & Results & Comments & References \\
\hline $\begin{array}{l}\text { CANADA } \\
\text { Premenopausal } \\
\text { women aged } \\
18-45 \text { with or } \\
\text { without VVS }\end{array}$ & $\begin{array}{l}40 \\
20 \mathrm{VVS} \\
20 \text { controls }\end{array}$ & $\begin{array}{l}\text { Touch and } \\
\text { Pressure } \\
\text { under } \\
\text { erotic } \\
\text { and neu- } \\
\text { tral condi- } \\
\text { tions } \\
\text { (erotic } \\
\text { film or } \\
\text { travel film } \\
\text { viewing) }\end{array}$ & $\begin{array}{l}\text { Tactile thresholds } \\
\text { Method of Limits, } \\
\text { using Modified } \\
\text { von Frey fila- } \\
\text { ments } \\
\text { Pain thresholds } \\
\text { Method of limits, } \\
\text { using } \\
\text { vulvalgesiometer } \\
\text { (spring-based } \\
\text { pressure device } \\
\text { with cotton swab } \\
\text { tip) } \\
\text { Sexual arousal } \\
\text { Labial thermistor } \\
\text { clip on labium } \\
\text { minus }\end{array}$ & $\begin{array}{l}\text { Vulvar vestibule (9- } \\
\text { o'clock) } \\
\text { Inner aspect of labium } \\
\text { minus } \\
\text { Volar surface of } \\
\text { foreram }\end{array}$ & $\begin{array}{l}\frac{\text { Genital vs. }}{\text { extragenital }} \\
\underline{\text { sites }} \\
\text { Forearm more } \\
\text { sensitive to } \\
\text { touch than } \\
\text { genital sites. } \\
\text { Vestibule more } \\
\text { sensitive to } \\
\text { touch than } \\
\text { labium minus. } \\
\text { Labium minus } \\
\text { more sensitive } \\
\text { to pain than } \\
\text { forearm. } \\
\text { Controls vs. } \\
\underline{V V S} \\
\text { VVS subjects } \\
\text { more sensitive } \\
\text { to touch and } \\
\text { pain than } \\
\text { healthy controls } \\
\text { under both } \\
\text { erotic and non } \\
\text { erotic condi- } \\
\text { tions }\end{array}$ & $\begin{array}{l}\text { Sexual arousal } \\
\text { had no effect } \\
\text { on extragenital } \\
\text { sensation } \\
\text { (forearm) } \\
\text { Forearm, } \\
\text { though more } \\
\text { sensitive to } \\
\text { touch, was } \\
\text { less sensitive } \\
\text { to pain than } \\
\text { the labia. } \\
\text { Data suggest } \\
\text { dyspareunia in } \\
\text { VVS patients } \\
\text { not due to lack } \\
\text { of arousal }\end{array}$ & {$[20]$} \\
\hline
\end{tabular}

A few studies have compared sensory perception among various sites on the vulva. A US study among 17 premenopausal women found slightly lower sensitivity to touch on the perineum, comparable sensitivity on the labia majora, labia minora, and clitoris, and slightly higher sensitivity on the anal verge [24]. A Canadian study of 13 premenopausal women found the one o'clock position of the vulvar vestibule to be more sensitive to touch than the 6- or 9-o'clock positions or the inner aspect of the labium minus [21]. Another study among 20 premenopausal women found the 9o'clock position of the vestibule to more sensitive to touch than the labium minus [20]. As noted earlier, a Dutch study reported that the vaginal wall was less sensitive to mild electric current than the labia majora, labia minora or clitoris [19].

As is the case at extragenital sites, vulvar sensitivity to mechanical stimuli deteriorates with age. A US study of 58 women aged 20-78 found that age affected both genital and peripheral sensation: vibratory thresholds increased progressively with age at the vulva, clitoris, external urethral meatus, perineum, and ankle [23]; on the vulva, the age effect first became apparent in the 30-39 age group. A study performed in Israel among 89 women aged 18-78 found that sensitivity to vibration decreased with age on the clitoris and on the anterior vagina, but that the effect of age on clitoral sensitivity was smaller [25]. In the latter experiment, the effect of age on vulvovaginal sensitivity to thermal stimuli was less straightforward: sensitivity to warmth decreased with age on the clitoris but remained constant on the anterior vagina; however, sensitivity to cold decreased with age on the anterior vagina but remained constant on the clitoris [25]. One small study examined the impact of the menstrual cycle on vulvar sensitivity to vibration, and found no effects at the clitoris, the hands, or the feet [22].

Along with age, the menopausal transition and the associated decline in estrogen levels appear to be critical determinants of the perception of touch on the vulva. The impact of estrogen status on vulvar and perineal sensitivity to punctate touch was demonstrated in a study of 38 women divided into five comparison groups: (1) premenopausal and postmenopausal women; (2) normoestrogenic women (premenopausal women and postmenopausal women on estrogen replacement therapy) and hypoestrogenic women (postmenopausal women not on estrogen replacement therapy); (3) women with and without clinical signs of vulvar atrophy; (4) neurologically impaired women and healthy controls matched by age, parity and estrogen status; and (5) women reporting sexual dysfunction and controls. SemmesWeinstein monofilaments were used to apply different intensities of punctate pressure to the glans clitoris, and bilateral sites on the labium minus and perineum, and the anal verge.

A clear effect of estrogen on vulvar sensitivity to punctate touch was demonstrated, with menopause, non-use of estrogen replacement therapy, and vulvar atrophy all associated with decreased clitoral, labial and overall vulvar sensitivity [24]. For perspective, thresholds to touch, averaged over all vulvar sites (clitoris, labium minus, perineum and anal verge), were 4.6-fold lower in normoestrogenic com- 
pared to hypoestrogenic women. Sexual dysfunction and neurological impairment also correlated with loss of vulvar sensitivity to touch.

Clinical trials of topical estrogen therapy support the conclusion that estrogen stimulation helps maintain vulvar sensory perception to touch. A prospective controlled trial examined the impact of topical estradiol cream applied to the vulvar vestibule and vaginal wall (either with and without biofeedback) in women with urogenital complaints aged 60 or older [26]. Topical estradiol cream was associated with a significant increase in vulvovaginal sensitivity to touch that improved as the duration of therapy progressed (specifically, after 4 weeks and 6 weeks of treatment). The greatest improvements occurred in women aged 70-79.

Lastly, a US study of women aged 20-78 found that whereas age affected both genital and extragenital vibratory sensation, menopausal status affected genital sensation only [23]. Taken together, these data indicate that the perception of punctate touch and vibration on the vulva and vagina is critically and uniquely dependent on estrogen status.

The perception of provoked vulvar pain is an issue of clinical importance. Some women with no identifiable pathology experience localized pain when pressure is applied to the vulvar vestibule. This idiopathic pain condition is known as provoked vestibulodynia or vulvar vestibulitis syndrome (VVS). Although a discussion of VVS is beyond the scope of this review, it is worth noting that QST has revealed objective, quantifiable differences in pain perception in women with this condition. Two Canadian studies examined vestibular perception of filament touch and touchinduced vestibular pain in premenopausal VVS patients and controls [20, 21]. A study with 13 nulliparous patients and 13 controls found tactile and pain thresholds on the vestibule to be dramatically lower in VVS patients than in controls. Specifically, tactile thresholds were about 4-fold lower and pain thresholds about 7-fold lower in VVS patients; moreover, levels of pressure that were perceived as touch by healthy controls caused pain in some VVS patients, and thresholds to touch in VVS patients were imperceptible to the controls [21]. A separate study examined the sensitivity of the vulvar vestibule to touch and pressure under neutral (travel film viewing) and erotic (erotic film viewing) conditions [20]. A labial thermistor applied to labium minus registered the level of arousal. Results showed the forearm to be more sensitive to touch than genital sites (vestibule or labium minus) but less sensitive to pain. On the vulva, the vestibule was more sensitive to touch than the labium minus. As in the previously cited study, VVS patients were more sensitive to vestibular touch than controls; sexual arousal increased vestibular sensitivity to touch in both patients and controls. However, in VVS patients, arousal also increased vestibular sensitivity to pain, whereas in healthy women, the pain sensitivity of the vestibule was unaffected. Sexual arousal had no impact on the sensation threshold to touch at an extragenital site (forearm). These data indicate that VVS patients have measurably heightened sensitivity to both vestibular touch and pain; moreover, dyspareunia in these patients is not necessarily due to a lack of sexual arousal but in fact may be exacerbated by it.
In summary, quantitative sensory testing (QST) indicates that the vulva is less sensitive to mechanical stimuli (touch, pressure) than some peripheral sites (e.g. the hand, forearm, deltoid muscle, thigh and abdomen); that vulvar sensitivity to punctate touch and vibration decreases with age; and that the perception of these stimuli deteriorates profoundly with the decline in physiological estrogen levels after menopause but can be restored with topical estrogen supplementation. QST also demonstrated that young women with VVS have a measurable, heightened sensitivity to vestibular touch and pain and that stimulus intensities perceived as touch by healthy women elicit pain in VVS patients.

\section{SUBJECTIVE VULVAR SENSATION IN CON- TROLLED TRIALS OF EXTERNAL HYGIENE PRODUCTS}

Further perspective on vulvar sensation is gained from prospective, randomized trials of external feminine hygiene products (menstrual pads, panty liners, and feminine wet wipes) in which participants reported sensory experiences of a more subjective quality. Over the past 26 years, dozens of randomized trials in various parts of the world have assessed observable vulvar irritation and subjective sensory effects associated the use of such products (reviewed in [27, 28]).

Women who use feminine hygiene products report a low frequency of vulvar sensory effects (such as rubbing, chaffing, burning, itch, or a moist, wet, sticky, or sweaty feeling). Data from a prospective randomized trial conducted in Greece are representative [29]. This trial in 115 menstruating women aged 18-45 assessed the skin effects of two thin menstrual pads that differed solely in the surface covering. Participants wore the assigned pads for menstrual protection over two consecutive cycles, and all participants wore the same panty liner design between menstrual periods. Objective visual scoring after each menstrual period or intermenstrually (close to midcycle) revealed few instances of visually perceptible vulvar irritation in either product group. A low frequency of sensory effects, specifically rubbing, itching and burning, was reported. About $1 \%$ percent to $2 \%$ of participants in each group reported any such effects after the first cycle; the frequency of reports dropped to between $0.4 \%$ and $1 \%$ after the second cycle.

Subjective sensory effects are less quantifiable and more complex that the simple perception of a single physical stimulus: rubbing is the perception of a mechanical stimulus (touch) combined with friction; the sensation of wetness may be a combination of the perception of fluid contact combined with a sensation of cooling through heat transfer and evaporation; itching and burning are subjective pathological sensations. Nevertheless, the frequencies of such effects in different groups of women also yield useful information on vulvar sensation.

A prospective trial of feminine wet wipes and dry toilet tissue conducted in France among groups of pre- and postmenopausal women is instructive. The trial examined both clinically observable skin irritation and wetness and subjective sensory responses to the two types of products in 120 premenopausal women aged $18-45$ and in 60 postmenopausal women aged 55 to 80 who were not on hormone replacement therapy [30]. Participants used either the wet 
wipes or dry tissue for menstrual or post-urination cleansing for 28 consecutive days (beginning 2-4 days before the onset of menstrual flow in premenopausal women). Premenopausal women were assessed on days 2-4 of the cycle and 2-4 days prior to the onset of the menstrual period. Postmenopausal women were assessed on study days $14 \pm 2$ and $28 \pm 2$.

In this study, objective vulvar erythema was either not observed, barely discernible, or slight in both product groups, with no statistical difference in frequencies between them. Reported sensory effects included slight burning, itching, or stinging (in both product groups) and a wet or sticky sensation (reported in the wet wipe product group only).

The frequencies of vulvar burning and itching in this study did not differ by menopausal status. A slight burning sensation was reported by $14 \%$ and $12.9 \%$ of premenopausal and postmenopausal wipes users, and by $1.8 \%$ and $3.4 \%$ of pre- and postmenopausal tissue users, respectively. Slight itch was reported by $1.6 \%$ and $3.2 \%$ of premenopausal and postmenopausal wipes users, compared to $7 \%$ and $0 \%$, of premenopausal and postmenopausal of tissue users, respectively.

Interestingly, the frequency of reports of vulvar wetness was not significantly different between premenopausal and postmenopausal wet wipes users (frequencies of $8 \%$ and $10 \%$, respectively), despite a clinically observable and statistically significant increase in skin moisture on the labia majora and perineum of postmenopausal women upon clinical examination. This observation is notable because it suggests that the perception of heightened vulvar wetness may have been attenuated in postmenopausal women. Postmenopausal women significantly preferred wet wipes to dry tissue for comfort (84\% of postmenopausal compared to $54 \%$ of premenopausal women rated the wet wipes excellent to very good for comfort.) An improvement in skin hydration may have contributed to their experience of greater comfort with the wet wipe product compared to dry tissue, if the postmenopausal vulvar tissue was atrophic. The experience of "comfort" could reflect a summation of several sensory effects.

Stinging was the only sensory reaction for which reported frequencies differed by menopausal status. Stinging is not an end-point typically associated with dry articles; $2 \%$ of premenopausal and $3 \%$ of postmenopausal women in the toilet tissue group reported slight stinging. Wet wipes users were more likely to report stinging, and premenopausal users reported a slight stinging sensation significantly more frequently than postmenopausal users (17\% vs. 9.6\%). This observation suggests that the sensory perception of sting on the vulva may be somewhat muted after menopause. The sensation of sting is of interest because dermatologists use the sting response to topically applied lactic acid as a surrogate marker for skin that is hyper-reactive to wind, temperature and chemical stimuli [31].

In summary, in a study of potential skin irritation and vulvar sensory effects of wet wipes, the sting response was less frequent in postmenopausal women; moreover, these women did not perceive vulvar skin to be wet with any higher frequency following use of the wet wipes, even though this product led to a clinically discernible rise in vul- var wetness among these women when compared to premenopausal wipe users. Consequently, sensations of sting and wetness appear to have been attenuated in postmenopausal women. However, perceptions of burning and itching were unaffected by menopausal status. We speculate that the perception of burning and itching on the vulva may be conserved to a greater degree with age because these sensations play a role in signaling pathology (e.g. vulvovaginal infection, contact dermatitis, and systemic vulvar dermatoses). Indeed, some pathological conditions that accompanied by itch (e.g. lichen sclerosus) are more prevalent in older women.

\section{EPIDEMIOLOGIC STUDIES OF GENITAL SENSA- TION}

A large percentage of people in industrialized countries consider their skin to be "sensitive" [32-34], although this is a self-declared condition lacking objective diagnostic criteria. Few systematic studies have been performed on ethnic differences in genital sensory perception. Limited evidence comes from a large epidemiological study of the perception of sensitive skin in the US by age, gender and ethnicity, based on responses to a questionnaire among 1039 people [32]. The perception of having slight, moderate, or very sensitive skin on the face or the body did not depend on ethnicity, but a higher percentage of African Americans $(66.4 \%)$ than whites $(54.2 \%)$ perceived their genital skin to be sensitive. This was true of both genders: $65 \%$ of African American men and $37.3 \%$ of white men reported genital skin sensitivity; $66.7 \%$ of African American women compared with $57 \%$ of white women considered their genital skin to be sensitive. Interestingly, older people were also more likely to claim sensitivity on the genitalia but not on the face and body. The characteristics of the sensations leading to these perceptions of sensitivity were not reported.

\section{CONCLUSIONS}

Quantitative sensory testing has been used to assess the perception of mechanical, thermal, and electrical stimuli on various parts of the anatomy, including the external female genitalia. QST studies indicate that in healthy women, the vulva is less sensitive to mechanical stimuli (touch, pressure) than some peripheral sites (e.g. the hand, forearm, deltoid muscle, thigh and abdomen). Perhaps the relatively low sensitivity of the labia minora, vestibule, and vagina to mechanical stimuli in healthy women represents an adaptation to the mechanical forces endured during sexual intercourse and childbirth. Interestingly, evidence also exists that the vulva is relatively insensitive to skin irritation induced by either menses or blood when compared to extragenital sites such as the skin of the upper arm. This could be a necessary adaptation to menstruation [35].

Sensitivity to punctate mechanical stimuli on the vulva in healthy women decreases with age, although limited data suggest that clitoral sensitivity to mechanical stimuli does not deteriorate as rapidly with age as does the perception of such stimuli at other vulvar sites. Although the sensitivity to mechanical stimuli declines with age both on the vulva and at extragenital sites, the decline in vulvar sensitivity to punctate touch is linked to the level of estrogen stimulation of the 
vulva: perception declines after menopause, but is restored by systemic or topical estrogen supplementation. Estrogen was not shown to affect perception of these stimuli at extragenital sites.

One caveat is that conclusions about the postmenopausal decline in vulvar sensitivity to touch are based on applying fine punctate pressure to defined locations. Perception of other types of stimuli may not be affected in the same way. For example, the mechanical properties of vulvar tissue, skin barrier function, and vaginal lubrication are altered after menopause, and postmenopausal women report higher levels of subjective sensations, such as irritation and discomfort, associated with these atrophic vulvar changes [36, 37]. Subjective sensory effects reported in clinical trials provide further evidence that estrogen status does not affect all forms of vulvar sensory perception in the same way. In clinical trials of external hygiene products, the frequency of slight vulvar burning and itching in response to physical contact with wet wipes or dry tissue was unaffected by menopausal status, but the stinging response (which, when measured on the face, is often associated with hyper-reactive or "sensitive" skin) appeared to be muted in postmenopausal women. Different sensory pathways in the vulva may be differentially affected by age or estrogen status.

Lastly, in contrast to healthy women, women with a pain dysfunction known as provoked vestibulodynia (vulvar vestibulitis syndrome, or VVS) have a measurably heightened sensitivity to vestibular touch and pain; mechanical stimulus intensities perceived as touch by healthy women elicit pain in VVS patients. QST studies have been helpful in quantifying and validating these differences.

Although the techniques reviewed herein provide some insights, systematic inquiry into vulvar sensory perception is hindered by the lack of standardized assessment methodologies for this morphologically complex tissue. Foundational work is needed to validate the experimental conditions used and to enable comparisons between experiments. Moreover, in the vulva, glabrous and semiglabrous keratinized skin are juxtaposed with areas of nonkeratinized mucosa, tissues that differ in their embryonic derivation and structure [38]. Factors such as labial shape and thickness may affect the way the stimuli are applied, and stimulus of the labia may affect sensation at other sites, such as the clitoris or vulvar vestibule. For example, in our laboratories, we (DZ) have found that a non-painful increase in physical traction on the labia majora increases the pain sensitivity of the vulvar mucosa (vestibule) by an average of 30\% (unpublished data). Furthermore, the direction of pressure applied to the vestibular mucosa (tangential vs. perpendicular) significantly affects sensory perception at this site, but has only a marginal effect on glabrous skin (unpublished data). The challenge of assessing sensation on closely juxtaposed skin and mucosal sites that vary both anatomically and functionally is not unique to the vulva: orofacial researchers address similar challenges [39] and some of their approaches may be useful to the study of vulvar sensation. Future research will seek to standardize and validate conditions for applying stimuli and measuring responses and investigate various anatomical, neurological, and dermatological factors that affect vulvar sensory perception.

\section{ACKNOWLEDGEMENT}

The authors acknowledge Deborah Hutchins, PhD ELS, of Hutchins \& Associates, LLC (Cincinnati, OH) for contributions to the literature review and technical writing assistance.

\section{CONFLICT OF INTEREST}

None declared.

\section{REFERENCES}

[1] Parnell BA, Johnson EA, Zolnoun DA. Genitofemoral and perineal neuralgia after transobdurator midurethral sling. Obstet Gynecol 2011;119(2): 428-31.

[2] Dyck PJ, Karnes J, O'Brien PC, Zimmerman IR. Detection thresholds of cutaneous sensation in humans. Peripheral Neuropathy 1993; 1: 706-28.

[3] Sheffield D, Biles PL, Orom H, Maixner W, Sheps DS. Race and sex differences in cutaneous pain perception. Psychosom Med 2000 Jul-Aug; 62(4): 517-23.

[4] Wasner GL, Brock JA. Determinants of thermal pain thresholds in normal subjects. Clin Neurophysiol 2008; 119(10): 2389-95.

[5] Zatzick DF, Dimsdale JE. Cultural variations in response to painful stimuli. Psychosom Med 1990; 52(5): 544-57.

[6] Lin YH, Hsieh SC, Chao CC, Chang YC, Hsieh ST. Influence of aging on thermal and vibratory thresholds of quantitative sensory testing. J Peripher Nerv Syst 2005; 10(3): 269-81.

[7] Shy ME, Frohman EM, So YT, et al. Quantitative sensory testing: report of the therapeutics and technology assessment subcommittee of the american academy of neurology. Neurology 2003; 60(6): 898-904.

[8] Doeland HJ, Nauta JJ, van Zandbergen JB, et al. The relationship of cold and warmth cutaneous sensation to age and gender. Muscle Nerve 1989; 12(9): 712-5.

[9] Bartlett G, Stewart JD, Tamblyn R, Abrahamowicz M. Normal distributions of thermal and vibration sensory thresholds. Muscle Nerve 1998; 21(3): 367-74.

[10] Hilz MJ, Axelrod FB, Hermann K, Haertl U, Duetsch M, Neundorfer B. Normative values of vibratory perception in 530 children, juveniles and adults aged 3-79 years. J Neurol Sci 1998; 159(2): 219-25.

[11] Kenshalo DR, Sr. Somesthetic sensitivity in young and elderly humans. J Gerontol 1986; 41(6): 732-42.

[12] Seah SA, Griffin MJ. Normal values for thermotactile and vibrotactile thresholds in males and females. Int Arch Occup Environ Health 2008; 81(5): 535-43.

[13] Komiyama O, Kawara M, De Laat A. Ethnic differences regarding tactile and pain thresholds in the trigeminal region. J Pain 2007; 8(4): 363-9.

[14] Rahim-Williams FB, Riley JL 3rd, Herrera D, Campbell CM, Hastie BA, Fillingim RB. Ethnic identity predicts experimental pain sensitivity in African Americans and Hispanics. Pain 2007; 129(1-2): 177-84.

[15] Campbell CM, Edwards RR, Fillingim RB. Ethnic differences in responses to multiple experimental pain stimuli. Pain 2005; 113(12): 20-6.

[16] Edwards RR, Fillingim RB. Ethnic differences in thermal pain responses. Psychosom Med 1999; 61(3): 346-54.

[17] Mechlin MB, Maixner W, Light KC, Fisher JM, Girdler SS African Americans show alterations in endogenous pain regulatory mechanisms and reduced pain tolerance to experimental pain procedures. Psychosom Med 2005; 67(6): 948-56.

[18] Wang H, Papoiu AD, Coghill RC, Patel T, Wang N, Yosipovitch G. Ethnic differences in pain, itch and thermal detection in response to topical capsaicin: African Americans display a notably limited hyperalgesia and neurogenic inflammation. Br J Dermatol 2009; 162(5):1023-9.

[19] Weijmar SWC, van de Wiel HB, Klatter JA, Sturm BE, Nauta J. Vaginal sensitivity to electric stimuli: theoretical and practical implications. Arch Sex Behav 1989; 18(2): 87-95.

[20] Payne KA, Binik YM, Pukall CF, Thaler L, Amsel R, Khalife S. Effects of sexual arousal on genital and non-genital sensation: a 
comparison of women with vulvar vestibulitis syndrome and healthy controls. Arch Sex Behav 2007; 36(2): 289-300.

[21] Pukall CF, Binik YM, Khalife S, Amsel R, Abbott FV. Vestibular tactile and pain thresholds in women with vulvar vestibulitis syndrome. Pain 2002; 96(1-2): 163-75.

[22] Helstrom L, Lundberg PO. Vibratory perception thresholds in the female genital region. Acta Neurol Scand 1992; 86(6): 635-7.

[23] Connell K, Guess MK, Bleustein CB, et al. Effects of age, menopause, and comorbidities on neurological function of the female genitalia. Int J Impot Res 2005; 17(1): 63-70.

[24] Romanzi LJ, Groutz A, Feroz F, Blaivas JG. Evaluation of female external genitalia sensitivity to pressure/touch: a preliminary prospective study using Semmes-Weinstein monofilaments. Urology 2001; 57(6): 1145-50.

[25] Vardi Y, Gruenwald I, Sprecher E, Gertman I, Yartnitsky D. Normative values for female genital sensation. Urology 2000; 56(6): 1035-40.

[26] Foster DC, Palmer M, Marks J. Effect of vulvovaginal estrogen on sensorimotor response of the lower genital tract: a randomized controlled trial. Obstet Gynecol 1999; 94(2): 232-7.

[27] Farage MA, Elsner P, Maibach H. Influence of usage practices, ethnicity and climate on the skin compatibility of sanitary pads. Arch Gynecol Obstet 2007; 275(6): 415-27.

[28] Farage MA, Stadler A, Elsner P, Maibach HI. Safety evaluation of modern feminine hygiene pads: two decades of use. Female Patient 2004; 29: 23-30.

[29] Farage MA, Katsarou A, Tsagroni E, et al. Cutaneous and sensory effects of two sanitary pads with distinct surface materials: a randomized prospective trial. Cutan Ocular Toxicol 2005; 24: 227 41.

[30] Farage MA, Stadler A, Chassard D, Pelisse M. A randomized prospective trial of the cutaneous and sensory effects of feminine hygiene wet wipes. J Reprod Med 2008; 53(10): 765-73.

[31] Muizzuddin N, Marenus KD, Maes DH. Factors defining sensitive skin and its treatment. Am J Contact Dermat 1998; 9(3): 170-5.

[32] Farage MA. How do perceptions of sensitive skin differ at different anatomical sites? An epidemiological study. Clin Exp Dermatol 2009; 34(8): e521-30.

[33] Jourdain R, Lacharriere O, Bastien P, Maibach HI. Ethnic variations in self-perceived sensitive skin: epidemiological survey. Contact Dermat 2002; 46(3): 162-9.

[34] Willis CM, Shaw S, De Lacharriere O, et al. Sensitive skin: an epidemiological study. Br J Dermatol 2001; 145(2): 258-63.

[35] Farage MA, Warren R, Wang-Weigand S. The vulva is relatively insensitive to menses-induced irritation. Cutan Ocular Toxicol 2005; 24: 243-6.

[36] Johnston SL, Farrell SA, Bouchard C, et al. The detection and management of vaginal atrophy. J Obstet Gynaecol Can 2004 26(5): 503-15.

[37] Farage MA, Maibach H. Lifetime changes in the vulva and vagina. Arch Gynecol Obstet 2006; 273(4): 195-202.

[38] Sargeant P, Moate R, Harris JE, Morrison GD. Ultrastructural study of the epithelium of the normal human vulva. J Submicrosc Cytol Pathol 1996; 28(2): 161-70.

[39] Pigg M, Baad-Hansen L, Svensson P, Drangsholt M, List T. Reliability of intraoral quantitative sensory testing (QST). Pain $2010 ; 148(2): 220-6$

(C) Farage et al.; Licensee Bentham Open.

This is an open access article licensed under the terms of the Creative Commons Attribution Non-Commercial License (http:/creativecommons.org/ licenses/by-nc/3.0/) which permits unrestricted, non-commercial use, distribution and reproduction in any medium, provided the work is properly cited. 